\title{
UMA REVOLUÇÃO CHAMADA BOCAGE: INADAPTAÇÃO E LIBERTAÇÃO
}

\author{
Eloísa Porto Corrêa*
}

Resumo: O presente artigo aborda as marcas da inadaptação social e diferentes maneiras de se pregar a liberdade na obra revolucionária de Bocage, poeta em trânsito entre dois mundos, o neoclássico iluminista e o romântico anti-iluminista. Para tanto, estabelecendo diálogos com a fortuna crítica bocageana, analisaremos algumas poesias líricas, satíricas e obscenas do autor. O estudo se justifica pela necessidade de entendermos melhor o conjunto da obra de Bocage, que ora satiriza tiranos, hipócritas e medíocres; ora enfoca o amor puro, ora o sensual, em cenários luminosos ou noturnos, ora em uma linguagem polida, ora obscena; construindo uma vasta galeria de figuras femininas castas ou libertinas, tiranas ou tiranizadas, amadas por um eu poético libertário, numa sociedade opressora e moralista. Além disso, a obra do poeta se revela fértil terreno para o estudo crítico da arte e do contexto histórico-cultural da segunda metade do século XVIII.

Palavras-chave: Bocage; Iluminismo; Revolução; Inadaptação; Libertação.

Abstract: This article talks about social maladjustment and different
ways to search freedom in the revolutionary poetry of Bocage, poet
between two worlds, the Enlightenment neoclassical and the
romantic. Therefore, establishing dialogues with the critical work
of the Bocage, we analyze some poems lyrical, satirical and bawdy.
The study is justified by the need to better understand the whole
work of Bocage, which satirizes tyrants, hypocrites and mediocre,
focuses on caste love, sometimes the sensual. In light or nighttime

* Universidade Estadual do Rio de Janeiro. 
scenarios, sometimes in a polished language, sometimes obscene, he builds a vast gallery of female figures castes or libertines, loved by a poetic-self libertarian, an oppressive society and morality. In addition, the work of the poet reveals fertile ground for the critical study of art and historical-cultural context of the second half of the eighteenth century.

Keywords: Bocage; Enlightenment; Revolution; Maladjustment; Freedom.

\section{Ideais Iluministas e contra-iluministas na poesia bocageana}

A obra multifacetada e revolucionária de Bocage (17651805), segundo Pires (2005), vem sendo insistentemente simplificada por estereótipos e associações com anedotários e pornografias tão distintos da poesia libertária que o poeta criou. Entretanto, para além dessas visões populares e não raro equívocas, a poesia de Bocage revela inadaptação a valores tradicionais e busca por libertação, verdadeiras filosofias de vida bocageanas, recorrentes seja na poesia lírica mais estudada de Bocage, na sátira ou na sua poesia obscena menos divulgada.

Essa busca de liberdade e a contestação a padrões e tradições na poesia de Bocage espelham alguns ideais iluministas adotados por intelectuais, artistas e até certos líderes políticos ocidentais do século XVIII, os quais propunham reformas na estrutura política e social do Absolutismo e na doutrina econômica mercantilista; combatiam a intolerância e os abusos da Igreja Católica, da nobreza e de políticos; e reivindicavam ampliação dos direitos civis, da liberdade de pensamento e expressão, pautados no poder da razão, do esclarecimento e da ciência. Tais ideais foram fundamentados pelos princípios da Ilustração, resumidos por Rouanet (1992, p. 152-153) em três: 1- "cognitivismo", a ideia de que "a moral podia ter um fundamento secular" comprometido com interesses de certos grupos sociais (clero, nobreza...); 2- "individualismo", "o indivíduo, 
considerado como célula elementar da sociedade, tinha direito à autorealização e à felicidade"; e 3- "universalismo", "existiria uma natureza humana universal" historicamente reprimida por tais grupos sociais no Ocidente.

Com isso, a obra de Bocage se insere no que Alexandrian (1993, p. 161-220) chama de "A idade de ouro da libertinagem" e da incredulidade, em que se nota quase sempre um "homem emancipado dos preconceitos religiosos", segundo Rouanet (1998, p. 167), e o gosto corrente na Europa do século XVIII pelas críticas ao Antigo Regime, pelas sátiras anticlericais e pelo panfleto revolucionário (ou difamatório), como também pela exaltação aos costumes populares e mundanos e pela obscenidade.

Apesar de, no século XVIII, o povo português no geral não se incomodar por ter que viver segundo os dogmas católicos, nem se sentir atrasado em relação às demais nações europeias; Cidade (2005, p. 17-19) mostra que houve uma crise mental, uma conscientização por parte de uma elite intelectual e artística sobre o atraso e a situação de decadência vividos no Portugal de então, tanto em face das outras nações europeias, quanto em comparação com o "vanguardismo vivido na Península em Quinhentos" (CARVALHO, 2007, p.6). Por isso, ainda que nem sempre se admita a existência de um Iluminismo português, em virtude de ideias modernas se articularem com a tradição católica muitas vezes no ambiente intelectual luso, a reforma que a Coroa portuguesa empreendeu na Universidade de Coimbra em 1772 popularizou e "institucionalizou muitos dos princípios ilustrados", segundo Carvalho (2007, p. 5-28).

Entre esses ideais iluministas que transparecem em obras de Bocage, temos sobretudo os de liberdade, igualdade e fraternidade, bandeira da Revolução Francesa que, segundo Hobsbawm (1996, p. 83), levou "os franceses, bem como seus numerosos simpatizantes no exterior", a encararem "a libertação da França como o primeiro passo para o triunfo universal da liberdade, uma atitude que levou facilmente à convicção de que 
era dever da revolução libertar todos os povos que gemiam debaixo da opressão e da tirania". É essa concepção libertária que encontramos em poesias como "Liberdade onde estás? Quem te demora?" e na "Epístola a Marília", também conhecida como "Pavorosa Ilusão da Eternidade", contra o clero, a moral vigente e a tirania, como se pode notar nos versos abaixo:

Ei-lo, cheio de um Deus, tão mau como ele,

Ei-lo citando os hórridos exemplos

Em que aterrada observe a fantasia

Um Deus algoz, a vítima o seu povo:

(...)

Ah! Bárbaro impostor, monstro sedento

De crimes, de ais, de lágrimas, de estragos,

(...)

Esse, de quem te ostentas tão válido,

É Deus de teu furor, Deus do teu gênio,

Deus criado por ti, Deus necessário

Aos tiranos da terra, aos que te imitam,

E àqueles, que não creem que Deus existe. (Grifos nossos)

Nessa poesia fica clara a denúncia e a desmistificação do fanatismo religioso, da hipocrisia do clero, de uma moral católica contrária à natureza humana e do conceito de um Deus castigador, bem como a crítica ao despotismo de muitos líderes políticos, que se aproveitavam da doutrina católica para justificar seus atos ("hórridos exemplos") de usurpação ao bem público e opressão ao povo. Em outras palavras, o eu poético se opõe aos "monarcas hereditários pela graça de Deus", que "comandavam hierarquias de nobres proprietários, apoiados pela organização tradicional e a ortodoxia das igrejas" e denuncia "uma crescente desordem das instituições que nada tinham a recomendá-las exceto um longo passado", de que nos fala Hobsbawm (1996, p. 38). Com isso, Bocage revela sua insubordinação a doutrinas católicas, instituições e sistemas políticos, endossando as "concepções religiosas, morais, políticas e sociais da Ilustração", como faziam vários autores libertinos nessa época, segundo Rouanet (1998, p. 178). 
Por causa de poesias críticas como essa, Bocage é preso, acusado de conspiração contra a segurança do Estado. Depois, mesmo inocentado desta acusação, é considerado culpado por erros contra a fé, obtendo redução de pena e transferência para a prisão no Mosteiro de São Bento. Mas, ainda insubordinado, acaba transferido para o Hospício das Necessidades. No cárcere, continua escrevendo poesias e epístolas. Livre, trabalha como tradutor de obras de Ovídio, Tasso, Racine, Voltaire e Vergílio. Sempre envolvido em polêmicas, cria várias poesias satíricas para desafetos, como "Franças, Semedos, Quintanilhas, / Macedos e outras pestes condenadas", sócios da Nova Arcádia, academia literária que o poeta ajudou a restaurar e da qual participou por um tempo, segundo Lemos (1972, p. 132), até passar a acusá-los de artificialismo, convencionalismo e padronização nas poesias produzidas, como se observa também nos versos: "Vós, néscios, que mamais das vis quadrilhas/ Do baixo vulgo insossas gargalhadas,/ Por versos maus, por trovas aleijadas". Enquanto aponta o lugar comum da obra de seus opositores, exalta a grandeza de sua própria poesia, sua originalidade e seu talento: "Deixai Elmano, que inocente e honrado/ Nunca de vós se lembra, meditando/ Em coisas sérias, de mais alto estado". Satiriza, com isso, não apenas literatos de uma elite intelectual privilegiada que hipocritamente condenam privilégios do Antigo Regime; mas também poderosos, novos-ricos, clérigos, médicos, avarentos, figuras que considera medíocres, hipócritas ou puritanas e castradoras ou vaidosas. Desta forma, em consonância com a "Boemia Literária", Bocage se mostra comprometido "com a tarefa de inverter o mundo, virando-o às avessas”, segundo Darnton $(1987$, p. 207).

Mas, na segunda metade do século XVIII, muitos pensadores acabam se afastando das primeiras teorias iluministas, constituindo um pensamento contra-iluminista, que contesta a hegemonia da razão e da ciência como formas privilegiadas de conhecimento e intervenção social, de acordo com Rauanet (1998, p. 167-196). Além disso, segundo Hobsbawm (1996, p. 284), "uma moda" entre intelectuais ligados com a boemia, como Bocage, era exaltar a "loucura". 
Também a obra de Bocage revela marcas desse contrailuminismo, como já notou Leodegário Azevedo Filho (2003). Em poesias como "Importuna Razão não me persigas", por exemplo, o eu lírico "procura mostrar que a razão é insuficiente para dominar o poder do amor", segundo Murta (1966, p. 16), e que não dá conta da complexidade humana muitas vezes: "Razão, de que me serve o teu socorro?/ Mandas-me não amar, eu ardo, eu amo;/ Dizes-me que sossegue, eu peno, eu morro". O homem nem sempre consegue seguir a razão ou a racionalidade, que nem sempre bastam ao ser humano, como se nota também na poesia "Minh'alma quer lutar com meu tormento", na qual o eu lírico desenganado afirma que "Mais vale que delire o pensamento/ Té agora coa Razão debalde armado", pois seguir a razão não foi suficiente para afastar o sofrimento, a "desesperação" e até o delírio: "O sofrimento azeda o que recata; (...) Tiraniza, consome, e às vezes mata." A experiência do eu lírico parece desenganá-lo sobre o poder da razão, enfraquecida pelo sofrimento, pela dor, pelo delírio e até pela loucura: "Importuna Razão não me persigas/ (...) Deixa-me apreciar minha loucura". Além de desconfiar da competência da razão como guia de seus pensamentos e atos passados e presentes, em outras poesias, o eu lírico não concebe a razão como capaz de orientar seu futuro, lamentando sua falta de perspectivas: "Some aos olhos mortais a luz futura", por causa do "fado inimigo", "espectro perseguidor, que anda comigo" e porque os "prazeres de algum dia" são "tão belos, tão duráveis como as flores" (MURTA, p. 24-41). A luz, símbolo de razão, ciência e perspectivas positivas de futuro, não é vislumbrada pelo eu lírico e, com isso, torna-se inviável a satisfação pessoal, até porque os prazeres são efêmeros para ele.

A razão e a ciência, portanto, nem sempre se mostram capazes de satisfazer o ser humano ou de melhorar as condições de vida dele, como pretendiam os primeiros iluministas. Por isso, aplicando à poesia de Bocage as palavras de Bataille (2006, p. 99), séculos mais tarde, sobre o racionalismo, percebemos que "o esforço pela compreensão racional termina em contradição" e "a 
prática de escatologia intelectual requer a excreção dos elementos inassimiláveis", pois não podem ser sistematizados. A experiência do eu lírico bocageano contradiz o império da ciência e da razão, revelam-nas como incapazes de gerar justiça social e melhorar a vida humana, as relações interpessoais e políticas. Por isso, o esforço do eu lírico bocageano por se guiar pela razão termina na contradição do desengano, do espectro, da loucura, que o levam à excreção da razão, já que experiências a contradizem ou revelam sua falha. Com isso, notamos que na gênese do texto de Bocage está "um discurso que tantas vezes despreza a Razão - em oposição ao Iluminismo que pontificou em opções de carácter filosófico", dando lugar "ao extravasar torrencial do sentimento", segundo Pires (2005). Desta forma, a obra de Bocage oscila entre o elogio da razão e sua excreção, entre a liberdade demandada e o controle do "Antigo Regime" português, que silenciava e perseguia opositores, perpetuando sua hierarquia rígida, seus padrões morais conservadores e a falta de diálogo, numa "modorra de província" que Bocage quer abalar com "as novidades vindas dos centros de agitação intelectual ou mundana”, segundo Pécora (1996, p. 113).

Assim, Bocage "tem uma relação ambígua com todas as ideias da Ilustração"; ele as difunde, mas, "ao contrário de outros autores libertinos, ele frequentemente as perverte". Da mesma forma que Elmano Sadino "investe contra todos os valores do Antigo Regime, e nisso é aliado das Luzes, agride também os valores da Ilustração" (ROUANET, 1998, p. 178).

\section{O claro-escuro na obra de Bocage}

A pluralidade é uma marca da obra de Bocage, que leva Artur Anselmo (1972, p. 130) a considerá-lo "um escritor em trânsito, herdeiro e aprendiz do Arcadismo de salão, mas já casado com o aceno tumultuário do iluminismo" e do contra-iluminismo romântico, como acrescenta Azevedo Filho (2003). Endossam essa 
pluralidade até as formas poéticas escolhidas por Bocage para a sua produção literária: poesia lírica, satírica, erótica, epístola..., que servem a fins tão distintos, como ridicularizar, escandalizar, exaltar, lamentar...

Esses fatos fazem com que "a genealogia do poeta não se estabeleça com simplicidade", pois toda a sua obra "decorre no conflito entre dois momentos distintos": 1- "um momento passado, traduzindo a adesão luminosa" e provisória "a uma escola ou a uma ideia", que resulta na "poesia de exaltação e idílio"; e 2- "um momento presente, afirmando o repúdio satírico ou noturno dessa escola ou ideia" (ANSELMO, 1972, p. 130, grifos nossos). Por isso, opõem-se duas vertentes principais em termos de temáticas, atitudes e cenários na lírica bocageana, segundo Pires (2005): (1) uma luminosa e etérea, em que o eu lírico evoca a amada, inebria-se com a beleza dela (Marília, Jónia, Anarda, Anália...) e expressa sua experiência amorosa em cenários bucólicos e pastoris, que refletem uma natureza luminosa e pagã, com zéfiros, ninfas, prado ameno, borboletas de mil cores e rouxinóis. Mas, por outro lado, numa via oposta, na (2) vertente noturna, encontramos cenários horrendos em outras poesias de Bocage, duplicando o pessimismo do eu lírico, que expressa suas desventuras, sua dor, a opressão ou a traição sofridas por ele, a indiferença, a ingratidão ou a tirania de suas amadas Gertrúria, Nise, Armia, Flérida, Alcina, Urselina...

Jacinto do Prado Coelho (1972, p. 124) chama essas duas vertentes da obra de Bocage de ciclos opostos, de forma que "ao ciclo de poemas malditos - os poemas do amor vil, do falso amor - contrapõe-se o ciclo do amor ascensional, purificante". Por isso, define Bocage como "poeta de claro-escuro, ora de sombras noturnas" e irracionais, carregadas de ideologias contrailuministas; ora de serena luminosidade", mais racional e imbuída de ideologias iluministas. Considera-o "poeta do amor, como algo absoluto, que eleva os homens acima de si próprios", mas também poeta que menospreza o que considera preconceitos sociais, numa 
"linguagem impetuosa, fremente, de vocabulário intenso e sintaxe emotiva", em versos bem medidos e musicais (COELHO, 1972, p. 124). É o que se nota num rápido confronto entre os sonetos decassílabos com rimas interpoladas "Já se afestou de nós o inverno agreste" e "O corvo grasnador e o mocho feio".

No primeiro, num cenário luminoso de "fértil primavera", "entre Zéfiros e Amores", o eu lírico convida Marília para o idílio amoroso, festejando o amor correspondido e voluptuoso com o desfrute dos prazeres da Natureza, princípio da Ilustração (ROUANET, 1992, p. 153). A poesia luminosa, assinada pelo pastor bucólico Elmano Sadino, pseudônimo pastoril de Bocage, é inspirado nos neoclássicos e segue postulados da Arcádia, que valorizam "a imitação superior da Natureza, a obediência a modelos clássicos, a elevação moral e social da literatura, a clareza e a simetria, o uso da mitologia com sentido alegórico, a exigência de verossimilhança, o equilíbrio em oposição a qualquer excesso"; na mesma medida em que "condena o cultismo e o conceptismo" do estilo barroco, "entendido como rebuscado, exagerado e artificial", segundo Azevedo Filho (2003, p. 5-9). Por isso, Bocage é cultuado por muitos em seu tempo, como pelos partidários do Elmanismo, que tem origem nas louvações que Filinto Elísio, exilado na França, faz a Bocage, seu herdeiro poético. Isso vira uma troca de elogios mútuos, que dá origem a duas correntes divergentes dentro da poesia portuguesa, mas não inimigas: elmanistas e filintistas.

Mas, essa poesia luminosa de Bocage é considerada por Cidade (1972, p. 127) uma "armadura clássica", já que "trespassada nas junturas pela substância romântica temperamental, em fervor" ("Eu louco, eu cego, eu mísero, eu perdido/ De ti só trago cheia, oh Jónia, a mente;/ Do mais e de mim ando esquecido"), que transborda na poesia noturna de Bocage. Como se viu, o anseio de liberdade leva Bocage, muito mais, a se libertar inclusive da razão, da lógica e da tradição, a transgredir normas, expressando com intensidade sentimentos e experiências e a fazer apologia da 
solidão. Há, portanto, uma clara prevalência da poesia de repúdio satírico ou noturno, que resulta na melhor parte da obra de Bocage, para Coelho (1972, p. 125), pois revela:

(...) uma vida emocional intensa, a humanidade das fraquezas e contradições, dos conflitos íntimos, dos apelos, a angústia perante o invisível, o diálogo transido com as forças ocultas do inconsciente, a sensação poética de malogro (tão camoniana), do total isolamento, a atração do nada (...) numa linguagem capaz de um visualismo simbólico e duma densidade sugestiva que transmitem de modo lapidar, envolvente, motivos profundamente vividos.

Na poesia "O corvo grasnador e o mocho feio", observamos esse visualismo simbólico na construção de imagens assustadoras, também a sensação de malogro, isolamento e fraqueza do eu lírico diante da dor. Num cenário noturno e horrendo, o choro do eu lírico ("Onde carpindo estou, de angústia cheio”), por causa da solidão e do sofrimento amoroso ("Perdi todo o prazer, todo o recreio,/ Ah, malfadado amor, paixão funesta!/ Urselina perdi, nada me resta"), duplica os pios de animais agoureiros e hostis "na floresta", que endossam o desejo de morte e evasão da dor e da frustração: "Madre terra! Agasalha-me em teu seio// Da víbora mordaz permite, oh Sorte,/ Que nos matos aspérrimos que piso/ As plantas me envenene o tênue corte!”. A morte nesta poesia seduz e atrai, pela possibilidade de paz, esquecimento e descanso, ainda que em outras poesias a possibilidade de morte horrorize $o$ eu lírico. Acompanhando esse desengano e o desejo de morte, como lembra Mendes (1972, p. 28), aparecem os espaços infernais, "labirintos, abismos, grutas, cárceres" e "matos aspérrimos".

É o que também ocorre nos versos de outra poesia: "Ânsias terríveis, íntimos tormentos,/ Negras imagens, hórridas lembranças,/ Amargosas, mortais desconfianças/ Deixai-me sossegar alguns momentos/ (...) Deixai-me confiar na formosura/ Crueis! Deixaime crer num doce engano". No fragmento, notamos intensas 
emoções; conflitos íntimos do eu lírico entre o turbilhão de tormentos e a atração do nada; apelos por sossego, angústia perante o invisível e um diálogo do eu lírico com as forças ocultas do seu próprio inconsciente; causados muitas vezes por sua inadaptação ao ambiente e busca por libertação da dor.

Além desses temas, segundo Mendes (1972, p. 28), o ciúme passa a ser abordado na poesia noturna de Bocage depois que, ao voltar do Oriente, encontra seu irmão casado com Gertrúria, o que é sentido por ele como uma dupla traição: "Eu deliro, Gertrúria, eu desespero/ No inferno de suspeitas e temores." Contrastando com o ciúme e a traição, o eu lírico evidencia seu amor puro ("ferve esta alma em cândidos amores") e desinteressado ("Longe o prazer de ilícitos favores!", "Quero o teu coração, mais nada quero"). Mais uma vez, ele se sente como num labirinto sem saída: "Ah! não sejas também qual é comigo/ A cega divindade, a Sorte dura./A vária Deusa, que me nega abrigo!// Tudo perdi: mas valha-me a ternura/Amor me valha, e pague-me contigo/Os roubos que me faz a má ventura". Por isso, o eu lírico lamenta sua miséria emocional e material: "Tudo perdi: mas valha-me a ternura". Deseja que no campo emocional não se repita sua desventura e pede à amada que não lhe tire "a ternura" ("Amor me valha, e pague-me contigo/ Os roubos que me faz a má ventura"), desejando que ela não seja como a "sorte dura": "que me nega abrigo!".

Por causa dessas figuras femininas ingratas e desses amores funestos que lhe causam "temor", "desespero", "angústias e horrores", notamos que o eu lírico inadaptado de Bocage busca uma figura feminina redentora e um amor ascensional, que o libertem do seu sofrimento, em poesias como a ode à Nossa Senhora da Encarnação e as três odes e um soneto à Imaculada Conceição. A figura da Imaculada Conceição, a "Virgem das virgens", "Doce abrigo, santíssima guarida", remete a um só tempo para todos os ideais femininos: "Mãe, filha, esposa, e mais que tudo amada", a quem o eu lírico pede proteção, colo e alento: "Valha-me o teu poder, e amor materno;/ Guia este cego, arranca- 
me da estrada,/ Que vai parar ao tenebroso inferno!". Com isso, valoriza e diviniza a mulher e busca religação com o feminino, seja com as figuras familiares da mãe, da irmã e da esposa ou das amadas; seja com o sagrado da divindade feminina: "tu, que do assanhado/ Tartáreo monstro com teu pé sagrado/ Esmagaste a cabeça intumescida". Ele opõe essas figuras e divindades femininas louvadas à divindade masculina deslouvada em poesias como "Epístola a Marília", já comentada; revelando em todos os casos uma carência da presença feminina e uma fragilidade do eu lírico: "De quem te busca (Imaculada Conceição) em lágrimas banhado/ Corrente com que as nódoas do pecado/ Lava uma alma que geme arrependida".

Assim, em sua perseguição à felicidade, princípio da Ilustração, Bocage enfoca ora o amor puro, ora o sensual; ora a traição e a frustração; ora o desejo da proteção e do alento feminino. Com isso, constrói uma vasta galeria de figuras femininas, "inventando mulheres quiméricas ou idealizando mulheres de carne e osso que depressa o decepcionam, quando não o desiludem", segundo Coelho (1972, p. 124-125); mas sempre revelando a força feminina. Além disso, ao produzir ora poesias luminosas, que elogiam a razão; ora noturnas, que abordam a desrazão, Bocage marca a convivência de ideologias iluministas e anti-iluministas no século XVIII.

\section{Insubmissão e Obscenidade}

A poesia mais revolucionária e insubmissa de Bocage é sem dúvida a obscena, que atenta contra o pudor, combate a repressão, busca liberdade sexual e defende posturas bem diferentes das do padrão religioso. Aliás, segundo Hobsbawm (1996, p. 284), no fim do século XVIII, "uma moda" entre "os gênios revolucionários", geralmente "incompreendidos, pobres" e ligados "com o submundo e a boemia", como Bocage, era exaltar "coisas normalmente censuradas pelos respeitáveis padrões e instituições", e chocar com "extremismos eróticos". É o que ocorre 
nas "Cartas de Olinda e Alzira", nas quais duas jovens, uma adolescente e outra mais velha, relatam suas aventuras sexuais em primeira pessoa, compondo um verdadeiro hino à insurreição feminina, como podemos notar no trecho a seguir, extraído da "Epístola IV", de Alzira a Olinda:

Quem ousa amor chamar crime execrando?...

Ah! deixa, Olinda, deixa que alardeiem

Virtude austera hipócritas infames:

Sabe que, enquanto amor horrivel pintam,

Enquanto aos olhos teus assim o afeiam,

De uma amante venal nos torpes braços

Vão esconder transportes, que os devoram,

$\mathrm{E}$, por castigo seu, somente gozam

Emprestadas carícias, vis afagos.

Mas quando assim os homens dissimulam,

Para dissimulares te dão direito:

Finge, como eles; ama e lho disfarça;

Que é mais um gosto amar às escondidas.

No fragmento, as jovens dialogam sem reservas sobre sexo, em busca da auto-realização pessoal, contestando a "moral secular" e seguindo a natureza humana, princípios da Ilustração de que fala Rouanet (1998, p. 152). Além disso, manifestam perplexidades, tecem críticas, confessam desejos íntimos e saboreiam convictamente suas transgressões, o que se confirma na "Epístola VI", de Alzira a Olinda:

A temerosa Olinda é quem me escreve?

É este o seu pudor, sua inocência?

Ah! Que as minhas lições tão bem aceitas,

Dão-me a ver que a discípula inexperta

Há-de em breve ensinar a própria mestra.

Olinda não sabia o que excitava

Dentro em seu coração ternos impulsos.

Que tanto a angustiavam... Não sabia

Qual de estranhas mudanças em suas formas,

Em seus membros gentis a causa fosse! 
A voluptuosa Olinda, devorada

Do mais ativo fogo, ingenuamente

Consulta a sua amiga, e a um leve aceno

Corre a engolfar-se na amorosa lida.

Basta um momento a transformá-la toda!

Os preconceitos de carácter sexual e a educação castradora são problematizados e desmistificados nas cartas, como também o são as obrigações femininas no casamento e as acusações da Igreja às mulheres, tidas como perdição dos homens.

Para Pires (2005), a poesia erótica ou obscena de Bocage adquire uma dimensão mais profunda e mais libertária do que a sua poesia luminosa árcade, do que a noturna e mais até do que a satírica, já que denuncia e combate a repressão sexual, contrária à natureza humana, e também contesta instituições, como o casamento e a família. É na poesia obscena que o eu poético liberta a mulher para o prazer carnal, questionando as bases da sociedade e a hipocrisia corrente. Até na escolha vocabular, optando por palavrões e expressões obscenas, atenta contra os padrões vigentes, usando termos mais explícitos para designar seres, partes ou ações humanas, como no verso "Canto a beleza, canto a putaria”. Se nas poesias noturnas Bocage manifesta variadas frustrações e nas satíricas denuncia escarnecedoramente todo tipo de problemas sócio-políticos; na poesia obscena põe em xeque os padrões sociais e revela seu desajuste e insubordinação inclusive em termos sexuais e linguísticos.

Para isso, Bocage celebra o "baixo amor", o amor puramente carnal, mais natural, mais livre, sem compromisso e sem a dor da perda, só prazer e deleite. Ele enfoca diferentes formas de amor, o sublime, o puro e até o sensual na poesia lírica. Mas, é com o "baixo amor" da poesia obscena, que o eu poético bocageano parece mais à vontade ou mais feliz, já que as outras formas de amor muitas vezes lhe causam sofrimentos, carências ou ciúmes. Por isso, por vezes, ele dá "tom alto à matéria baixa", no dizer de Pécora (1996, p. 120). É o que se nota na descrição de 
Vênus na poesia "A Manteigui", na qual a deusa é celebrada por sua lascívia, numa clara referência à Vênus de Os Lusíadas de Camões: "a mais formosa entre as deidades,/ Mais lasciva também que todas elas,/ Tu, que vinhas de Tróia às soledades/ Dar a Anquises as mamas e as canelas,/ Que gramaste do pai das divindades/ Mais de seiscentas mil fornicadelas; / E matando uma vez da crica a sede,/ Foste pilhada na vulcânea rede". Na poesia, não apenas a beleza sensual da deusa é celebrada, mas também a sua iniciativa sexual, a exploração do corpo segundo sua própria vontade e a busca dela por satisfação dos desejos. $\mathrm{O}$ eu poético apresenta o sexo como positivo, natural e prazeroso, admirando e exaltando a figura feminina que o pratica sem falsos pudores.

Com isso, a poesia libertina e libertária de Bocage livra do pecado e da repressão sexual a mulher ou liberta a "puta" em cada mulher, certificando que "isto de virgo e honra é tudo peta". É o que se percebe também em "A minha Amada", na qual o eu poético se gaba da sensualidade e da beleza da sua amada: "Se tu visses, Josino, a minha amada,/ Havias de louvar o meu bom gosto"; "Na sua boca Vênus faz morada:/ Nos olhos Cupido as setas posto;/ Nas mamas faz Lascívia o seu encosto,/ Nela enfim tudo encanta, tudo agrada". A sensualidade da mulher não é escondida, nem motivo de vergonha ou de depreciação da figura feminina, antes é motivo para o eu poético se orgulhar e se sentir invejado pelos outros: "Beleza mais completa haver não pode:/ Pois mesmo o cono seu, quando palpita,/ Parece estar dizendo: 'Fode, fode!'. O ímpeto sexual dela, para o eu poético, é o que a torna mais completa em sua beleza, o que desmerece o padrão de beleza e comportamento feminino vigente, pautado na pureza e na castidade cristã.

Percebe-se que o eu poético da obra obscena de Bocage admira a mulher libidinosa, que usa seu corpo em busca de prazer ou até de sustento. Mas, ele critica e escarnece as que usam a sexualidade por ambição ou com finalidades lucrativas. Na poesia de Bocage, a prostituta não é condenada por obter recursos para o 
seu sustento com o ato sexual, mas as "damas" que ostentam imagem casta e usam ocultamente sua sexualidade para obter lucros, poder ou vantagens são ridicularizadas. Por isso, a dama Manteigui é acusada de "vil cobiça" no uso dos seus amores, motivo que leva "o vingativo Amor, como agravado" a "castigar-lhe" com "fogo infernal no coração (...) / Por um cafre asselvajado": "Tendolhe visto a tórrida linguiça/ Mais extensa que os canos dum telhado,/ Louca de comichões a indigna dama/ Salta nele, convida-o para a cama". A hipérbole na descrição das partes íntimas do "cafre" e a reação da dama, atraída pela aberração, acentuam o ridículo da situação em que ela se encontra. Cabe ressaltar que o castigo sofrido pela "indigna dama" não é por causa dos amores carnais, esses Olinda e Alzira também têm e não são condenadas por eles.

Maffei (2005) lembra que outras damas são apresentadas por Bocage como "putas" e depreciadas por usarem a sexualidade para obter vantagens políticas ou escalar a pirâmide social, à semelhança de Manteigui, como no soneto "Não lamentes, ó Nise, o teu estado". Essas "Putíssimas fidalgas [que] tem Lisboa”, como também Dido, Cleópatra, Lucrécia e a imperatriz da Rússia, são usadas como motivos na poesia para que a amada Nise não se envergonhe de sua situação de prostituta: "Puta tem sido gente muito boa,/ Milhões de vezes putas têm reinado"; "Cleópatra por puta alcança a c'roa;/ Tu, Lucrécia, com toda a tua proa,/ O teu cono não passa por honrado"; "Essa da Rússia imperatriz famosa,/ Que inda há pouco morreu (diz a Gazeta)/Entre mil porras expirou vaidosa". O eu lírico consola Nise, ridicularizando as fidalgas hipócritas, que usam o sexo para atingir suas ambições e ostentam fachadas distintas, puritanas, muitas vezes.

Ao construir imagens positivas para algumas prostitutas e apresentar o lado "puta" de certas damas, Bocage como sempre subverte a moral vigente em Portugal e na Europa e choca os moralistas, ainda mais numa época em que a mulher não costumava aparecer "em lugares protagonistas" (MAFFEI, 2005). Ao elogiar um comportamento feminino transgressor ao paradigma cristão, Bocage busca uma aproximação maior com a 
natureza humana, da qual não se exclui a sexualidade feminina: "Todas no mundo dão a sua greta". Com isso, também denuncia o quanto a castidade pregada pela Igreja é só aparentemente obedecida e rompe com a ideia de pecado.

Por isso, a obra de Bocage é uma das mais proibidas da literatura portuguesa, por ser não apenas revolucionária, mas sobretudo escandalosa e libertina em todos os sentidos: linguístico, sexual, político, religioso...

Enfim, a defesa de figuras humildes e marginais na obra de Bocage, como prostitutas, revela uma profunda identificação com o povo oprimido e sua inclinação, como de outros artistas libertinos setecentistas, para representar "costumes populares e mundanos" e "costumes sexuais do povo", segundo Alexandrian (1993, p. 170). Isso também se deve ao convívio quotidiano de Bocage com deserdados e marginalizados de toda a ordem, durante sua vida boêmia em Portugal ou no Brasil, onde esteve durante o seu serviço militar, iniciado aos $\mathbf{1 6}$ anos, após fugir de casa e se alistar no Exército, depois na Marinha; ou na Índia, em que também serviu; ou ainda em Cantão, China e Macau, lugares por onde vagou depois de desertar. Bocage, para Pires (2005), ao consubstanciar a voz do povo oprimido, encarna o inconsciente coletivo do povo português, de forma crítica, compensando com riso, caricatura e ridículo a sua insatisfação, como já antes fizeram os poetas medievais nas cantigas de escárnio e maldizer.

\section{O fim}

Enquanto prostitutas, mulheres e divindades femininas são exaltadas em poesias de Bocage, apresentadas muitas vezes como fonte de conforto e abrigo; em "Pavorosa Ilusão de Eternidade", como se viu, o Deus cristão e os líderes religiosos e políticos são associados ao despotismo, à injustiça, à prisão e à falsidade. Raras vezes a divindade masculina é invocada como possível salvadora na obra de Bocage, como alguns críticos leem 
em poesias do segundo volume das Rimas, publicadas em 1799, quando Bocage estava já pobre, doente e reconciliado com antigos desafetos, antes de morrer em 21 de dezembro de 1805.

Mas, como as poesias de Bocage, sobretudo as do final da vida do poeta, apresentam múltiplas dimensões e interpretações, os críticos são levados a divergências. Enquanto Artur Anselmo (1972, p. 130) lê "palavras que têm o peso da contrição" em "Meu ser evaporei na lida insana", Adelto Gonçalves (2003) afirma que Bocage continuou a se opor ao poder vigente (clero e monarquia), ainda que em alguns de seus versos sugerisse o contrário, para evitar problemas com os censores régios:

Meu ser evaporei na lida insana

Do tropel de paixões, que me arrastava;

Ah! cego eu cria, ah! mísero eu sonhava

Em mim quase imortal a essência humana.

De que inúmeros sóis a mente ufana

Existência falaz me não dourava!

Mas eis sucumbe a Natureza escrava

Ao mal, que a vida em sua orgia dana.

Prazeres, sócios meus, e meus tiranos!

Esta alma, que sedenta em si não coube,

No abismo vos sumiu dos desenganos.

Deus, oh Deus!... Quando a morte à luz me roube, Ganhe um momento o que perderam anos, Saiba morrer o que viver não soube.

A "lida insana/ Do tropel das paixões" bem pode ser a luta apaixonada do eu lírico contra poderosos, opressores e tradições, que lhe evaporaram as forças e lhe renderam perseguições e prisões: "que me arrastava". Esta leitura segue pistas de críticos como Gonçalves (2003), que apontam a possibilidade de leituras mais subversivas para poesias como a acima, além daquelas da tradição crítica, que costuma ver a divindade masculina cristã invocada como possível salvador para um eu lírico arrependido da "vida em sua orgia dana". 
Ao lado dos amores ilícitos e da vida desregrada, os ideais políticos ou as transgressões mundanas podem ter entusiasmado o eu lírico, que sonha e persegue a possibilidade de um mundo mais livre: "Ah! cego eu cria, ah! mísero eu sonhava". Talvez, o entusiasmo o tenha levado a superestimar suas possibilidades de transformação do sonho em realidade ou a superestimar suas próprias forças e mecanismos de luta e transformação social. Por isso, este homem, "esta alma, que sedenta em si não coube", sequiosa de prazeres, de transgressão, de liberdade e de luta por transformações, "sucumbe", exausta ou fracassada.

Os "prazeres, sócios meus, e meus tiranos!" podem ser entendidos como a vida boêmia, os inimigos (como os sócios da Nova Arcádia) e os tiranos que oprimem e desenganam o eu lírico, entre os quais bem podem ser inseridos os censores e até o Deus cristão, que Bocage aponta em outras poesias como castigador e que, por isso mesmo, pode não perdoar o eu lírico e nem lhe dar "um momento" de defesa na morte.

De uma forma ou de outra, nessa poesia também o eu lírico se declara um inadaptado ainda e sempre: "o que viver não soube", pois não se conformou ao senso comum, aos paradigmas correntes, à moral vigente, nem à estética neoclássica, ao Catolicismo, ao Iluminismo, ao racionalismo ou ao cientificismo, mesmo quando parece renegar suas poesias mais insubmissas, como acima. A poesia de Bocage dialogou com muitos paradigmas e ideologias, mas o seu ímpeto transgressor e libertário não lhe permitiram obediência por muito tempo a nenhum grupo ou cânone, salvo em exceções, que ocorrem pela necessidade. É a luta pela vida que leva o poeta por vezes a disfarçar a transgressão para enganar a censura, como ele próprio atesta: "E se entre versos mil de sentimento/ Encontrardes alguns, cuja aparência/Indique festival contentamento,// Crede, ó mortais, que foram com violência/ Escritos pela mão do Fingimento,/ Cantados pela voz da Dependência”. Dessa necessidade de sobrevivência é que podem ter saído algumas louvações a figuras públicas em sua poesia, como se defende o eu lírico. 
Entretanto, mesmo miserável, perseguido por diversos pretextos: ligação com a maçonaria, ideias subversivas, heresia...; mesmo censurado, preso, "reeducado" pela polícia política e pela enfraquecida Inquisição; Bocage continua arranjando maneiras de satirizar desafetos da Nova Arcádia, do clero e da política; medíocres, conservadores e moralistas, ainda que tenha que distribuir clandestinamente suas poesias, como várias vezes fez, ajudado por maçons, por exemplo.

Desta forma, Bocage acaba criando seu próprio "mundo libertino contra-iluminista", já que "aplicada a si mesma", pelo poeta, "a Ilustração se autocancela" (ROUANET, 1998, p. 195). Isso ocorre porque ele encontra o tempo todo "a autonegação da virtude, da igualdade e da liberdade", no crime, na hierarquia (com seus privilégios) e na tirania (ROUANET, 1998, p. 195-196), vícios que vê continuarem a ocorrer mesmo entre ilustrados e iluministas, como denuncia em sua obra.

Assim, o poeta inadaptado e transgressor de tradições constitui com sua poesia incontida e escandalosa uma galeria de figuras, situações, ideias e problemas setecentistas, ora satirizando tiranos, hipócritas e medíocres; ora focalizando figuras humildes, puras ou "putas"; enfocando o amor puro ou o sensual, em cenários luminosos ou noturnos; sempre problematizando valores, questionando paradigmas de comportamento. Com isso, busca abalar a sociedade opressora e moralista do Portugal do século XVIII e persegue sempre o desejo de libertar a pátria, os concidadãos, a mulher e a si próprio dos tiranos e dos pecados.

\section{REFERÊNCIAS}

ALEXANDRIAN. A Idade de Ouro da Libertinagem. In: História da Literatura Erótica. Rio de Janeiro: Rocco, 1993. p. 161-220.

ANSELMO, A. Bocage e a crítica. In: Bocage: Gigantes da Literatura Universal. Lisboa: Verbo, 1972. 
AZEVEDO FILHO, L. A. de. O Contra-Iluminismo na Poesia de Bocage. Rio de Janeiro, SBLL, 2003.

BATAILLE, G. Visions of excess: selected writings, 1927-1939. Minneapolis: University of Minnesota Press, 2006.

BOCAGE. Antologia poética. 4. ed. Lisboa: Ulisseia, 2001.

BOCAGE. Obra completa - Volume VII: Poesias Eróticas, Burlescas e Satíricas. Porto: Caixotim, 2004.

BOCAGE. Poemas. Rio de Janeiro: Nova Fronteira, 1987.

CARVALHO, F. R. Um Iluminismo Português? A Reforma da Universidade de Coimbra de 1772. Brasília: UnB, 2007.

CIDADE, H. Bocage e a crítica. In: Bocage: Gigantes da Literatura Universal. Lisboa: Verbo, 1972.

CIDADE, H. Ensaio sobre a crise cultural do século XVIII. Lisboa: Presença, 2005.

COELHO, J. do P. Bocage e a crítica. In: Bocage: Gigantes da Literatura Universal. Lisboa: Verbo, 1972.

DARNTON, R. Boemia Literária e Revolução: o submundo das letras no Antigo Regime. São Paulo: Cia das Letras, 1987.

DARNTON, R.; ROCHE, D. (Org.). Revolução Impressa: a imprensa na França 1775-1800. São Paulo: EdUSP, 1996.

GONÇALVES, Adelto. Bocage: O Perfil Perdido. Lisboa: Caminho, 2003. HOBSBAWM, E. J. A Era das Revoluções: Europa 1789 - 1848. Rio de Janeiro: Paz e Terra, 1996.

LEMOS, E. de. Elmanismo e Filintismo. In: Bocage: Gigantes da Literatura Universal. Lisboa: Verbo, 1972.

LEMOS, E. de. Bocage e a crítica. In: Bocage: Gigantes da Literatura Universal. Lisboa: Verbo, 1972.

LOURENÇO, E. Nós e a Europa: ou as duas razões. Lisboa: INCM, 1994. MACEDO, H. Camões e a Viagem Iniciática. Lisboa: Moraes Editores, 1980.

MACEDO, H. Rótulos. In: Trinta Leituras. Liboa: Editorial Presença, 2007. p. 269-270. 
MAFFEI, L. C. de S. Para sair da gaveta o Bocage obsceno. In: XX ENCONTRO DA ABRAPLIP. Anais... Niterói: UFF, 2005.

MENDES, J. Bocage de perto. In: Bocage: Gigantes da Literatura Universal. Lisboa: Verbo, 1972.

MURTA, G. (Seleção, prefácio e notas). Bocage: poesias. 4. ed. Lisboa: Sá da Costa, 1966.

NEMÉSIO, V. A vida e as obras de Bocage. In: Bocage: Gigantes da Literatura Universal. Lisboa: Verbo, 1972.

PÉCORA, A. Parnaso de Bocage, rei dos brejeiros. In: NOVAES, A (Org.). Libertinos e Libertários. São Paulo: Companhia das Letras, 1996. p. 103-136.

PIRES, D. Introdução. In: Bocage. Obra completa. Volume VII: Poesias Eróticas, Burlescas e Satíricas. Porto: Caixotim, 2004.

PIRES, D. Eis Bocage... duzentos anos depois. Bocage, poeta da liberdade. Poesia erótica de Bocage. Bocage lírico. Bocage tradutor. Uma perspectiva brasileira de Bocage. Bocage anedótico. In: Bocage 1765-1805. Lisboa: BN, 2005. In: http://purl.pt. Acesso em 22/10/2011, às $9 \mathrm{~h} 46 \mathrm{~min}$.

ROUANET, S. P. O Desejo Libertino entre o Iluminismo e o ContraIluminismo. In: NOVAES, A. (Org.). O Desejo. São Paulo: Companhia das Letras, 1998. p. 167-197.

ROUANET, S. P. Dilemas da moral iluminista. In: NOVAES, A. (Org.). Ética. São Paulo: Companhia das Letras, 1992. p. 149-162.

SOBOUL, A. A Revolução Francesa. Rio de Janeiro: Zahar, 1964.

Recebido para publicação em 28 de dezembro de 2012. Aprovado em 28 de maio de 2013. 